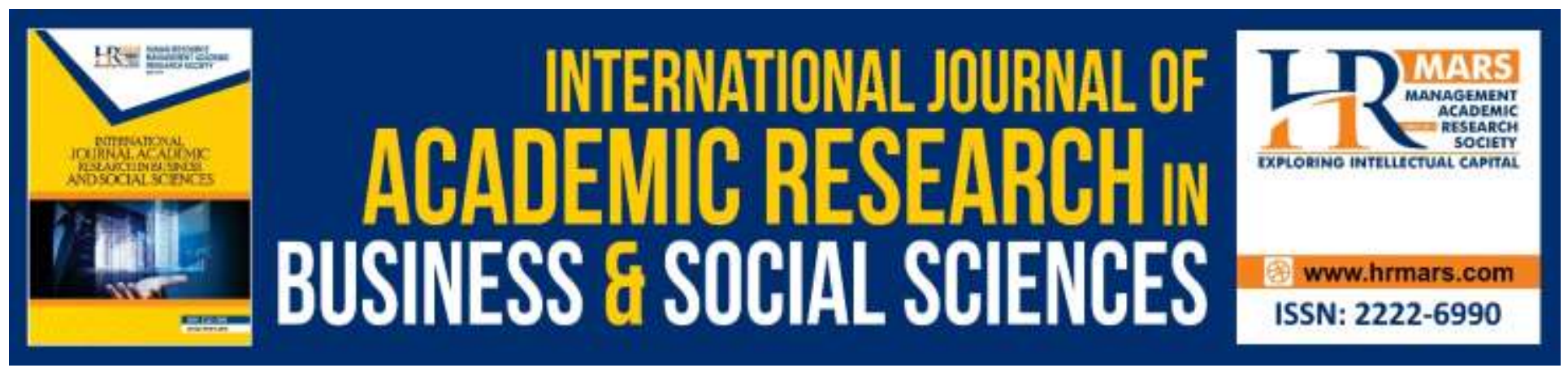

\title{
R.O. Winstedt' Notion on Islamic Criminal Laws in Malaya: An Analysis
}

Mohd Farhan Abd Rahman, Muhd Imran Abd Razak, Ahmad Firdaus Mohd Noor, Mukhamad Khafiz Abdul Basir, Nurul Khairiah Khalid \& Nor Adina Abdul Kadir

To Link this Article: http://dx.doi.org/10.6007/IJARBSS/v10-i3/7026

DOI:10.6007/IJARBSS/v10-i3/7026

Received: 21 January 2020, Revised: 04 February 2020, Accepted: 27 February 2020

Published Online: 24 March 2020

In-Text Citation: (Rahman et al., 2020)

To Cite this Article: Rahman, M. F. A., Razak, M. I. A., Noor, A. F. M., Basir, M. K. A., Khalid, N. K., \& Kadir, N. A. A. (2020). R.O. Winstedt' Notion on Islamic Criminal Laws in Malaya: An Analysis. International Journal of Academic Research in Business and Social Sciences, 10(3), 91-101.

Copyright: (C) 2020 The Author(s)

Published by Human Resource Management Academic Research Society (www.hrmars.com)

This article is published under the Creative Commons Attribution (CC BY 4.0) license. Anyone may reproduce, distribute, translate and create derivative works of this article (for both commercial and non-commercial purposes), subject to full attribution to the original publication and authors. The full terms of this license may be seen

at: http://creativecommons.org/licences/by/4.0/legalcode

Vol. 10, No. 3, 2020, Pg. $91-101$

http://hrmars.com/index.php/pages/detail/IJARBSS

JOURNAL HOMEPAGE

Full Terms \& Conditions of access and use can be found at http://hrmars.com/index.php/pages/detail/publication-ethics 


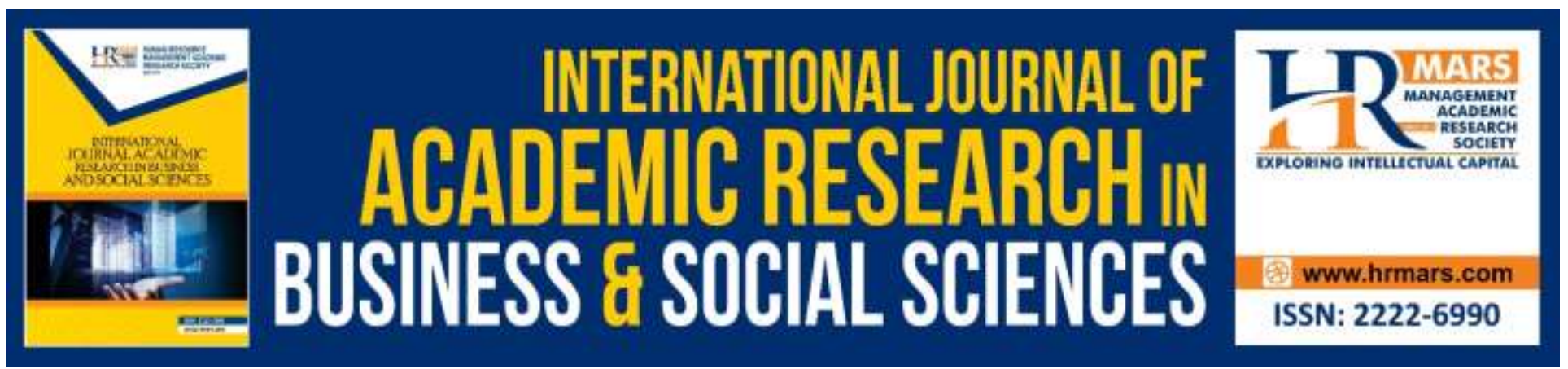

\title{
R.O. Winstedt' Notion on Islamic Criminal Laws in Malaya: An Analysis
}

\author{
Mohd Farhan Abd Rahman¹, Muhd Imran Abd Razak (Ph.D) ${ }^{1}$, \\ Ahmad Firdaus Mohd Noor (Ph.D) ${ }^{1}$, Mukhamad Khafiz Abdul Basir ${ }^{1}$, \\ Nurul Khairiah Khalid ${ }^{1}$ \& Nor Adina Abdul Kadir ${ }^{2}$ \\ ${ }^{1}$ Academy of Contemporary Islamic Studies (ACIS), MARA University of Technology (UiTM) Perak \\ Branch, Seri Iskandar Campus, 32610 Seri Iskandar, Perak, Malaysia, ${ }^{2}$ Academy of Contemporary \\ Islamic Studies (ACIS), MARA University of Technology (UiTM) Melaka Branch, Alor Gajah Campus, \\ 78000 Alor Gajah, Melaka, Malaysia
}

\begin{abstract}
R.O. Winstedt is an orientalist serving in Malaya as a British administrator. His form of thinking is founded by logical empirical of positivism; a philosophy utilizes ne plus ultra of reason as the primary degree to obtain exact truths based on systematic and thorough research methods. The philosophy declines to prove a fact acquired by revelation because it is considered irrelevant in historical verification. is focused on the analysis of Winstedt's notion of Islamic Criminal laws in Malaya indeed the orientalist approach in evaluating Islam and Malay and how far the acceptance of Islamic criminal law in the legal tradition of the Malay community. The writers apply historiography, comparing and content analyzing methodologies in this study. The findings suggest that orientalist thinking approaches, particularly Winstedt, have shown a debatable point of view and biased judgment in evaluating Islam i.e. the legal system. Winstedt believes Islamic laws and customary should not be mutually enforced because of the former is intolerable practices in Malaya on cultural and residential dichotomy. The notion is due to orientalists' shortcomings in understanding Islamic teaching in fact as a result of European-centric thinking. The thought assembles Europe as a great and civilized nation compared to other races, so-called the ambassador of civilization who are the savior of the nation that ought to be civilized.
\end{abstract}

Keywords: Islamic Criminal Laws, Customary Laws, Malaya, Logical Empirical of Positivism, Orientalist.

\section{Introduction}

Orientalism derived from orient with additional al and ism. Orient is a French vocabulary which means east. Geographically, the orient means the Eastern world, while ethnologically it is defined as the Eastern nations (Joesoef, 1985). While oriental in English means concerns relating to the East and ism means an understanding, doctrine, teaching, system, flow or attitude (Umar, 1978). 
INTERNATIONAL JOURNAL OF ACADEMIC RESEARCH IN BUSINESS AND SOCIAL SCIENCES

Vol. 10, No. 3, March, 2020, E-ISSN: 2222-6990 @ 2020 HRMARS

According to Rahman (2017), orientalism is a political thought intended to colonize and eliminate Eastern culture, especially Islam, thereby publicize Western civilization as a great thus, govern worldwide. To Said (1977), orientalism is a method to understand Eastern world based on Western's observation. It covers three different things but correlated, namely:

1) Orientalists are individuals who teach, write or perform a series of inquiries concerning Eastern world. This group consists of anthropologists, sociologists or philologists.

2) Orientalism is a thought based on the methodological differences of ontologism and epistemology between the East and West world.

3) Orientalism is a Western approach to dominate, restructure and direct Eastern society. Their concern is to create accounts, teach and control Eastern world including religion that mutable to their needs.

The aforementioned orientalism directions also pursues by Lughod (2001, 101-113). He said:

The way in which the Orient has been represented in Europe through an imaginative geography that divides East and West, confirming Western superiority and enabling, if not actually constituting, European dominance of those negatively portrayed regions known as East.

The tripartite scholars' opinion show that the Western colonialists intended to influence the Eastern world in terms of religion and culture, in actual fact disseminate secularism into intellectual of the colonists. Al-Attas (1978) consciousness pertaining to the hostility history between Christianity and Islam was through regional expansion and military assault, however the resistance furthers to intellectuality where the primary end is Muslims. He explains:

The confrontation between Western culture and civilization and Islam ... has now moved on to the intellectual level and we must realize, then, that this confrontation is by nature a historically permanent one. Islam is seen by the West as posing a challenge to its very way of life.

(Al-Attas 1978, 99)

The writers' study focuses on R. O. Winstedt, an orientalist who studies societies in Malaya especially Muslim. His areas of interest cover religion, culture, history and literature. To study Winstedt's notion of Islamic Criminal laws in Malaya, the writers attempt to compare and analyze his works such as in The Malays: A Cultural History, A History of Classical Malay Literature and A History of Malaya. While in Malaya, Winstedt in his conservative thought, struggle to create transformation where he believes only Western powers could advance humans instead of Islam, unfortunately it is unacceptance attitude to the Malay. The objective of the research is focused on the analysis of Winstedt's notion of Islamic Criminal laws in Malaya indeed the orientalist approach in evaluating Islam and Malay and how far the acceptance of Islamic criminal law in the customary law of the Malay community.

\section{Methodology}

This study focuses on Winstedt's notion to Islamic Criminal laws in Malaya indeed the orientalist approach in evaluating Islam and the Malay based on the examination of his selected works; The 
INTERNATIONAL JOURNAL OF ACADEMIC RESEARCH IN BUSINESS AND SOCIAL SCIENCES

Vol. 10, No. 3, March, 2020, E-ISSN: 2222-6990 @ 2020 HRMARS

Malays: A Cultural History, A History of Classical Malay Literature and A History of Malaya. To achieve the objective of the study, the writer have applied three approaches, namely the historiography, comparing and content analyzing methodologies.

\section{Historiography Method}

This method refers to problem findings from the historical accounts (Ferman \& Levin, 1975). It applies chronological and historical background to understand the development process with refer to evidences and facts of primary and secondary sources in the respective field. The writers have execute this method in identifying orientalists' approach in evaluating the Islamic laws in Malaya and Winstedt's view on Islamic Law specifically on Islamic Criminal Laws.

\section{Comparative Method}

This method is based on the middle approach in making evaluation (Ferman \& Levin, 1975). The study aims to produce an equitable and unbiased judgements. Any information obtained will be analyzed to abstain from skeptical understanding and ultimate partisan. The writers have applied this method to analyze Winstedt's works that are related to his view on the Islamic Criminal Law, and consequently compared similarities and dissimilarities of other academics views. It aims to dispel doubtful views on the Islamic Law.

\section{Content Analysis Method}

Thru primary and secondary sources, the writers analyze the work of Winstedt in terms of the quality of his writing indeed to his allegations against the Islamic Laws, who were claimed that the law does not have a strong influence over society in Malaya. The conclusion of the study is then derived from the final analysis result.

\section{Orientalists' Approach to Islamic Laws}

According to Rahman (2019), orientalists claim Islam is a deceitful religion created by the Prophet Muhammad (peace be upon him), and indeed labeled as a cultural religion produced by Arabs in the Middle East who confronted the hot climate then projecting violent and aggressive attitudes. Orientalists consider climate influenced a person's character, therefore Islam is said absolutely irrelevant as a way of life (Goldziher, 1981). Meanwhile, orientalists execute secularism that is free from any religious affluences, indeed outline standards and methodologies for conducting study of Islamic law:

First, a strict references quality standard is applied to study Islamic laws (Goldziher, 1981). The orientalists are meticulous in judging the certainty and validity of works by Muslim scholars. The facts comprehend by the latter being disputes by the former and overtly decides to adopt sources from classical orientalist scholars who prejudice upon Islam.

Second, any study concerning Islamic law should perform the higher criticism approach (Goldziher, 1981). This approach was initially used to prove the mistakes found in Christianity, then extend its application to Islam. Orientalists, admittedly try to prove errors in the Quran and al-Sunnah which is the main sources of Muslim.

Goldziher (1981) described the Islamic legal system as static and solemnly applicable in the Middle East. Pertaining to secularism, Western law is deemed as the highest legislation in the state government compared to Islamic laws, which is merely devoted to religious activities such as marriage. This is proven thru Constitutions of Malaya (Perlembagaan Tanah Melayu) set by Reid's 
INTERNATIONAL JOURNAL OF ACADEMIC RESEARCH IN BUSINESS AND SOCIAL SCIENCES Vol. 10, No. 3, March, 2020, E-ISSN: 2222-6990 @ 2020 HRMARS

Commission (Suruhanjaya Reid), that Islam is the official religion of the country for religious ceremonies but has no legislative jurisdiction (Spuler, 1960). The above mentions has visibly negate the contribution of Muslim scholars, who are the role play in modelling the great civilization of Malaya towards independence. To orientalists, if Malay requires progress, they should ignore the Islamic law, by all means substitute the Western legal system that is more practical and gratifying human will.

\section{R.O. Winstedt's General Views on Islamic Laws in Malaya}

The writers recognize one of Winstedts' works on Islamic legislation entitled The Malays: A Cultural History, who identifies and compares society adoption and adaption between Islamic laws and customary laws, especially the Minangkabau.

On the word of al-Attas (1978), Islamic law is the most just legislation and meets all human needs. In Malaya, the law nonetheless has been varied with customary laws, created by human beings to guard the position of certain groups such as the nobility. Winstedt (1969) explains the local laws that influenced by Islamic jurisdiction is Ninety-Nine Laws of Perak (Undang-Undang 99 Perak) where officially endorsed between $17^{\text {th }}$ and $18^{\text {th }}$ centuries, and he also assumes that the law has been amended in line to locality.

In addition, Winstedt (1961) also believes that the Customary Laws of Perpatih and Temenggong (Undang-undang Adat Perpatih dan Adat Temenggong) are two different types of legislation in Malaya. He explains that the latter (Adat Temenggong) induced of Islam and Hinduism. Meanwhile, the former (Adat Perpatih) is categorized solely the genuine law in Malaya because of no foreign interventions. Winstedt (1988) eventually perceives Islam as a major encumbrance to consolidate Malay law, especially in relation to custom, hence inapt to practice in Malaya. To clarify the above argument, the writers highlight opinion of Yan $(2009,140)$. He states:

They perceived Islam and Malay adat laws as irreconcilable and conflicting because Islamic laws originated from a different social context, so it could not practically serve the needs of the Malays.

He, then adds:

The colonial writers judged Islamic laws as static and arbitrary and that is has a negative impact upon the traditional Malay laws.

(Yan, 2009, 140)

The idea outlined by Yan is an authentication concerning orientalists dubious while evaluating facts, and obviously influenced by the classical orientalists due to hostility to Islam. Swettenham (1893) explains, the Eastern that adhere to religion is considered as a nation that refuses progress, thus needs to be civilized through the colonial process. The orientalists also label Islamic laws as cruel, static and merely appropriate to practice in the Middle East. Swettenham (2005) adds that the negative attitudes of the Malays are due to their strong faith on Islam such as submitting to fate, disrespecting time and refusing modernity. Therefore, transformation is needed by introducing Western thought systems, particularly legislation that is more relevant and flexible today.

Ibrahim and Joned (2005) clarifies, the signing of the Pangkor Treaty 1874 (Perjanjian Pangkor 1874) and the 1895 Federal Agreement (Perjanjian Persekutuan 1895) has continued the domination of the colonialist government in Malaya. The position of Islamic laws as the primary source of 
INTERNATIONAL JOURNAL OF ACADEMIC RESEARCH IN BUSINESS AND SOCIAL SCIENCES

Vol. 10, No. 3, March, 2020, E-ISSN: 2222-6990 ¿ 2020 HRMARS

legislation has been restricted seemly to marriage affairs. After enactment of the agreement, according to Rahman (2019), the British expanded their dominance by demeaning the existing Islamic government policies in the Malay states. The variation and compatibility between religion and customs of Muslim in Malaya were isolated, as well as the superiority of the sultanate institutions as a customary protector was uncertain.

\section{R.O. Winstedt's View on Islamic Criminal Laws}

Winstedt's work entitled The Malays: A Culture History has exposed his personal views on Islamic laws focusing crimes. Through his work, Winstedt devotes to compare the Customary Law of Temenggong and the Ninety-Nine laws of Perak. Winstedt $(1961,91)$ states:

There are digests, containing traces of Malay indigenous patriarchal law, but mixed with relics of Hindu law and overlaid with Muslim law. This patriarchal law is called Adat Temenggong or law of the Minister for war and police.

The idea was related to the type of punishment to be imposed on criminal offenders, besides conviction under Islamic laws, it also imposes a fine-tuned sentence to redeem each of the following offenses. Penalty offense for bulglary, Winstedt $(1961,102)$ explains:

As a rule, it gives the Muslim penalties for crime. Keeping close to Sunni law-books, it exempts the thief of a small sum from amputation. Under the law of Shafi i. homicide accompanied by robbery was punishable by death, and the corpse was to be exposed on a cross for three days; the Pahang supplement substitutes for crucifixion the ancient punishment of impaling, borrowed by the Malays from the Hindu as a punishment for robbery, and lays it down that the malefactor the impaled for three days.

Accordingly, Winstedt believes that there are influences of Hindu and Islamic teachings in the Temenggong Customary Law which led to unfounded understanding of the Islamic laws by Malays. They will encounter difficulties while determine the genuine and appropriate Islamic laws in order to solve problems. Under the Ninety-Nine Laws of Perak, Winstedt $(1961,103)$ says:

The Muslim guilty of homicide was to pay a fine and to provide a buffalo or a white goat or a white camel for the funeral feast. Even an infidel was not to be put to death for homicide.

The penalty fee for each offense is different according to the injuries degree imposed by the offender. For example:

As for wounding, if the hurt were above the navel, blood money of $\$ 25$ was to be paid; if below the navel, $\$ 5$, and if there were only slight bleeding, an offering of white cloth sufficed. Whatever crime a man 
INTERNATIONAL JOURNAL OF ACADEMIC RESEARCH IN BUSINESS AND SOCIAL SCIENCES Vol. 10, No. 3, March, 2020, E-ISSN: 2222-6990 ¿ 2020 HRMARS

committed, these Sayid Justifiers held that, provided he could pay the proper fine, his sins should be pardoned in this world.

(Winstedt 1961, 103)

According to Rigby (1908), in the criminal case of killing fellow Muslims, even the killer is withdraw from sentenced to death, the judge although will charged him five gold coins and be subjected to the feast by slaughtering a buffalo or a white goat. Contrary to non-Muslims kill Muslims, the former cannot be penalty by retaliation (qisas) whereas if the murderer is Muslim and the victim is non-Muslim, the murderer will be sentenced to death. To some circumstances, the murderer will be released if he is able to compensate for ten tyrants of gold to the deceased's family.

For the writers, ideas propose by Winstedt and Rigby pertaining Islamic laws has indicate their deficiencies. Their belief of Islamic laws are not suitable for practicing in Malaya where it has to be compressed according to locality yet is inaccurate. The understanding where the Malay needs to apart customs and prioritize Islamic laws, however would underestimate the latter and perceived as an encumbrance to the people who practice customs.

Winstedt also presents the position of customary laws against Islamic laws concerning hudud. He said:

Those taken in adultery might be stoned to death under Muhammadan Law. But over the relation of the sexes the adoption of that law was as gradual as in order fields of jurisprudence. Brutal as many of the penalties in the Malacca digest are, its mediaeval customary law was more lenient towards sexual offenses than contemporary Muslim practice.

(Winstedt 1961, 105)

Therefrom, he certainly signifies customary laws not malicious decrees indeed benevolent sincerely to the society, thru his expression of "was more lenient". To writers, Winstedt aimed to devalue the Islamic laws and its implementation to Malays in problem solving. Rahman (2016) highlights, the West intents to nurture the idea as to detach Muslim from Islamic principles, so that to renounce religion from in their lives. In addition, Winstedt adds:

According to the $18^{\text {th }}$ century Ninety-Nine Laws of Perak, the seducer of a betrothed girl was just fined and married off, that is, if he could pay the fine and provide double the dowry (half of it for the jilted suitor), though if the seducer could not pay, he was not to be married but banished, beaten and plundered; and if fines were not paid, the woman was to have her head shaved and be pilloried at the door of the mosque.

(Winstedt 1961, 105)

The above punitive standards in convicting criminal offenders are seen to be more succumb to customary such as fines and so on, compared to Islamic laws. Halimi (2007) postulates the NinetyNine Laws of Perak implicitly preserved personal interest of the elites such as aristocrats or individuals who possess status in society. 
INTERNATIONAL JOURNAL OF ACADEMIC RESEARCH IN BUSINESS AND SOCIAL SCIENCES Vol. 10, No. 3, March, 2020, E-ISSN: 2222-6990 ¿ 2020 HRMARS

Other types of offenses involving penalties are adultery. It is classified under hudud, though in Malaya the sentence has been aligned to local orders, hence it does not resemble Islamic commands. Winstedt $(1961,105)$ confirms:

In the Malacca digest it is stated that by customary law, if a man killed anyone making overtures to his wife or daughter, he was just fined, and if a man raped a slave-girl, he had only to marry her or be fined, whereas Shafi ite law would admittedly sentence him to death by lapidation.

The above mentioned demonstrates prejudices presence to the execution of law provision to criminal offenders. In fact, Winstedt visibly illustrates the reputation of Islamic laws in judging the affairs of the people in Malaya. Fang (1976) discloses the case of adultery, the Malacca Code of Law (Hukum Kanun Melaka) is known to be strictly in accordance with the provisions of Islamic laws, but the lack thereof the option of customary law recourse.

In addition, penalties are also regard as contribution profits to the government. Winstedt (1961, 108) says:

For not only was suppression of crime the main object of law in a port kingdom but fines were a profitable source of income to rulers and chiefs.

The law indirectly proposes facet of materialist while redeeming all punishment allocate to money or gold. To writers, the punishment enforcement is unjust because the rich may solves thru material goods, however oppressive to the helpless as the poor and slave.

The discourse by Winstedt obviously proves he refused the authority of Islamic laws. He leave the credibility of the law by subjecting to family law instead as a way of life. The writers also analyze views from Wilkinson, who conveyed the impact of Islamic laws on the lives of the people in Malaya, includes marriage, crime and so on. Either Islamic laws has produced profound platform on Malays or act as an additional law to be incorporated into customary laws. He clarifies:

Notwithstanding the influence of Muslim law in Malaya, it had not supplanted the local custom in its entirety. It was accepted in the religious matters, in family law and the law of succession, but in order matters the custom prevailed with only some Muslim additions incorporated in it in the course of centuries.

(Wilkinson 1908, 48)

Explanation presents by Wilkinson and as regards by orientalists, has proven that Islamic laws does not have a strong influence over society in Malaya. For the writers, both orientalists deliver negative interpretations on Islamic laws by all means to change society's attitude from stable to instable, even them admittedly aware Islam has influenced the thinking of the Malay.

To reinforce the above argument, the writers refer to Elias's position who stands out the reason for the negative evaluation of the colonialists against Islam including its legislation due to: 
INTERNATIONAL JOURNAL OF ACADEMIC RESEARCH IN BUSINESS AND SOCIAL SCIENCES Vol. 10, No. 3, March, 2020, E-ISSN: 2222-6990 @ 2020 HRMARS

Pengalaman beragama yang pahit dalam sejarah kebudayaan Barat serta pertembungan dengan agama serta kebudayaan Islam dalam sejarah dunia telah mencorakkan penilaian umum orientalis terhadap agama Islam. Keraguan yang terbit akibat dari sifat dan pembawaan agama mereka sendiri serta prasangka yang menebal terhadap hakikat risalah Islam serta pembawanya, akhirnya menjadikan kebenaran semua agama dilihat tidak lebih dari kebenaran falsafah. Agama yang ditanggapi dalam telaah sejarah penulis orientalis ini adalah agama yang mesti berubah mengikut peredaran zaman hingga mampu menjadi batu loncatan mencapai cita-cita pembangunan atau sebaliknya, agama yang jumud, yang layak dicerca sebagai batu penghalang. (Unscrupulous religious experiences in Western cultural history as well as clashes with Islamic religions and cultures in world history have designed the orientalist universal understanding of Islam. The doubts arising out of their nature and religious beliefs, and also dense prejudices against the veracity of Islam and the messengers, ultimately perceives all religious legitimacy are no more than a philosophy. The religion addressed by the historians' orientalist writers is a religion that need to change according to time space, so a stepping up as to achieve development or otherwise, a religion that is profane, which is worthy to be vilified as hindrances.)

(Elias 2012, 612)

Accordingly, the writers examine the views of Winstedt and Wilkinson are evidently based on historical facts who embedded prejudices so that Islam is regarded as incapable reaching the needs of the community and incompetent teachings to time space.

\section{Conclusion}

The contribution of this article to explain the position of the Islamic criminal law in Malaya and its contribution to Malay society is very clear. Winstedt's view on the appropriateness of criminal law practice Islam in Malaya and reception in customary law is biased. The arrival of Islam to Malaya for the writer did not eliminate the customary influence of the Malay. The arrival contributes positive advocacy as "led to a selective syncretization" i.e. any custom that is compatible and competent in Islam will be preserved. Notwithstanding, Winstedt's believes Islamic laws and customs cannot be mutually enforced because of the orientalist's perspectives, Islamic laws, and its content are not suitable for practicing in Malaya due to cultural and residential differences.

Winstedt's writings and approach have demonstrated skeptical views on Islam and the Malay, grounded by biased contemplations, hence deviate the history of Malay civilization. His deliberations originate in the evolution and diffusion paradigm of orientalism. He constructs the highest logical thought, to the basis that all traditions, knowledge standard and Islamic jurisprudence could be questioned in its authenticity.

Winstedt classed the Malay community as a pathetic nation that departs from progress and modernization due to embracing Islam. He yet fails to understand the Malay community because of European-centric thinking i.e. Euro-centrism. The thought projects the European nation as a great and civilized nation beyond other nations in Asia encompassing the Middle East as well as in Malaya. 
INTERNATIONAL JOURNAL OF ACADEMIC RESEARCH IN BUSINESS AND SOCIAL SCIENCES

Vol. 10, No. 3, March, 2020, E-ISSN: 2222-6990 @ 2020 HRMARS

The British were regarded as "ambassador of civilization", the savior of the people in the Malay in order to eliminate deficiencies and attain perfections. Even Winstedt proposes Euro-Centrism as a standard to study the history of Malaya, he had not yet understood the Malays, though was biased in interpreting Islam in Malaya.

\section{Corresponding Author}

Mohd Farhan Abd Rahman, Academy of Contemporary Islamic Studies (ACIS), MARA University of Technology (UiTM) Perak Branch, Seri Iskandar Campus, 32610 Seri Iskandar, Perak, Malaysia, Email: farhan84@uitm.edu.my.

\section{References}

Lughod, L. A. (2001). Orientalism and Middle East Feminist Studies. Feminist Studies, 27(1): 101-113. Al-Attas, S. M. N. (1978). Islam and Secularism. Kuala Lumpur: ABIM.

Elias, A. (2012). Kecenderungan Paksi India: Implikasinya Terhadap Pensejarahan Islam di Alam Melayu. In Ismail, M.Z. \& Abdullah, W.S.W. (Eds.). Adab dan Peradaban: Karya Pengi tirafan untuk Syed Muhammad Naquib al-Attas. Petaling Jaya: MPH Group Publishing Sdn. Bhd.

Fang, L. Y. (1976). Undang-Undang Melaka. The Hague: Martinus Nijhoff.

Ferman, G. S., \& Levin, J. (1975). Social Sciences Research. Amerika Syarikat: John Wisley \& Sons.

Goldziher, I. (1981). Introduction to Islamic Theology and Law. (Andras \& Ruth, H., Terj.). Princeton: Princeton University Press.

Halimi, A. J. (2007). Pengaruh Islam Terhadap Perundangan Melayu: Tumpuan Kepada Undangundang 99 Perak. In Zain, F.M. (Ed.). Islam di Tanah Melayu Abad ke-19. Shah Alam: Karisma Publications Sdn Bhd.

Ibrahim, A., \& Joned, A. (2005). Sistem Undang-Undang di Malaysia. Kuala Lumpur: Dewan Bahasa dan Pustaka.

Joesoef, S. H. M. (1985). Orientalisme dan Islam. Jakarta: Bulan Bintang.

Rahman, M. F. A., Aziz, N. H., Ahmat, A. C., Yusuf@Salleh, M. Y., \& Rahim, R. A. A. (2016). A Doctrinal Aspect of Orientalism and its Influences of Malay Culture. Journal e-Academia. 5(2): 58-65.

Rahman, M. F. A., Aziz, N. H., Kadir, N. A. A., \& Aris, N. F. M. (2017). Orientalist Studies Verge on Islam: Early History. International Journal of Academic Research in Business and Social Sciences. 7(12): 1246-1256.

Rahman, M. F. A., Razak, M. I. A., Noor, A. F. M., Basir, M. K. A., \& Khalid, N. K. (2019). Kedudukan Perundangan Jenayah Islam dan Adat ke atas Masyarakat Melayu di Tanah Melayu Menurut Pandangan Orientalis: Rujukan Khusus Terhadap R.O. Winstedt. Jurnal 'Ulwan. 4(1): 86-99.

Rahman, M. F. A., Razak, M. I. A., Noor, A. F. M., Basir, M. K. A., \& Khalid, N. K. (2019). Analysing Stages of the Western Orientalists' Approach towards Islam. International Journal of Academic Research in Business and Social Sciences. 9(9): 979-989.

Rigby, J. (1908). The Ninety-nine Laws of Perak. In Wilkinson, R.J. (Ed.). Papers on Malay Subjects: Law Part 1. Kuala Lumpur: Government of the Federated Malay State.

Said, E. W. (1977). Orientalism. London: Penguin.

Spuler, B. (1960). The Muslim World: A Historical Survey. Leiden: E.J. Brill.

Swettenham, F. (1893). About Perak. Singapura: Straits Times Press.

Swettenham, F. (2005). Perihal Orang Melayu. (Zubaidah, I., Terj.). Kuala Lumpur: Penerbit Universiti Malaya.

Umar, A. M. (1978). Orientalisme dan Kajian Tentang Islam. Jakarta: Bulan Bintang. 
INTERNATIONAL JOURNAL OF ACADEMIC RESEARCH IN BUSINESS AND SOCIAL SCIENCES

Vol. 10, No. 3, March, 2020, E-ISSN: 2222-6990 @ 2020 HRMARS

Wilkinson, R. J. (1908). Papers on Malay Subjects: Law Part 1. Kuala Lumpur: Government of the Federated Malay State.

Winstedt, R. O. (1961). The Malays: A Cultural History. London: Routledge \& Kegan Paul Ltd.

Winstedt, R. O. (1969). A History of Classical Malay Literature. Kuala Lumpur: Oxford University Press. Winstedt, R. O. (1988). A History of Malaya. Kuala Lumpur: Marican \& Sons.

Yan, C. Y. (2009). Colonial Image of Malay Adat Laws: A Critical Appraisal of Studies on Adat Laws in the Malay Peninsula during the Colonial Era and Some Continuities by Noor Aisha Abdul Rahman. New Era College Academic Journal. v. 6. 